\title{
Getting a Taste for the Bogong Moth
}

\author{
Kate Rigby
}

\section{Intruders}

Many years ago, one night in spring, a time of high exam anxiety for Australian university students, a friend of mine broke his college room window. The hour was late, his nerves on edge, and there is a chance that he might not have been entirely sober. His big mistake, though, was to have gone out leaving the window wide open. On his return he found his room aflutter with moths, and it was in the course of his frenzied attempts either to expel or to exterminate the vile intruders with a trusty textbook that said window was inadvertently smashed (thereby ensuring an ongoing infestation).

I cannot be sure now what manner of moths these were, but my ill-fated friend declared them to have been bogongs. Hearing this, my sympathy was assured. Like him, I had grown up in Canberra, and so had learned to dread the annual bogong moth invasion. Along with the long years of drought that wreaked havoc in our parents' well-kept gardens, bogongs rated high among our least favourite aspects of the indigenous environment for many Canberra kids of my generation, most of whose parents had moved to the 'bush capital' during its time of rapid expansion in the decade or so after the War. Lacking the dangerous charisma of other Aussie undesirables, such as red-back spiders, funnel-webs or tiger snakes, these largish, muddy-brown insects were the embodiment of abject otherness, their persistent knocking against uncurtained windows and sneaky incursions into closely guarded domestic interiors summoning inchoate fears and feelings of revulsion.

On reflection, the violent response of my book-wielding college friend might well have been the legacy of a barely remembered childhood moth trauma, dating from the Great Invasion of 1969 when we were both impressionable primary school kids. On that occasion, as I have recently discovered, the nation's capital fell prey to such a large bogong infestation that the automatic lifts and air-conditioning shafts of some high-rise office buildings were blocked by resting moths, while parts of the city even suffered power failures (Flood 74). There is no record of such a large moth migration since then, and in recent years, their numbers appear to have fallen off markedly. This might simply be a matter of natural cyclical variation; but as we shall see, the future of the bogong 
is far from assured. What chance is there, I wonder, that those who find this creature so very unlovable might yet come to lay it to heart, such that its fate could become a matter of widespread public concern?

From time to time, bogong moths do make the news: not just the college news, or the local news, but the national, and even international news. Most recently, they hit the headlines worldwide when several fell victim to the heatwave that stopped play during the women's final of the 2009 Australian Open tennis tournament in Melbourne. As the mercury soared to $43^{\circ}$ Celsius, leaving the players 'soaked in sweat and gasping for air' and sending spectators scuttling away to 'watch matches on television sets in bars and shaded areas at Melbourne Park', the 'brutal conditions proved too much for the swarms of bogong moths that flutter around the stadium's bright lights, with dozens dropping dead on to the main court' (Linden). Outside the stadium, over the unprecedented three days that followed of maximum temperatures topping $43^{\circ}$, flying foxes and possums also fell down dead in parks and gardens, while Melbourne's morgues overflowed with human fatalities. These deaths are now remembered as part of the ominous lead-up to the even more newsworthy firestorm that engulfed much of the state at the end of the following week: a catastrophe that doubtless owes at least part of its genesis to those anthropogenic climatic changes that could also bode ill for bogongs.

This was by no means the first time that bogongs had rated a mention in the reporting of an international sporting event in Australia, the most famous being the occasion when one allegedly made itself comfy on Yvonne Kenny's bosom as she sang the closing anthem of the 2000 Sydney Olympics. While doubt has been shed on the actual species identity of this particular moth (Herbison-Evans and Crossly), it would appear that not only the stadium but also, and especially, the toilet facilities were infested with bogongs, 'unnerving' many overseas visitors. While a spokeswoman for the event admitted that killing them was 'an option', one BBC sports reporter quipped that were they to be culled, 'restaurant menus might get interesting', since bogongs were said to be 'a culinary treat, possessing a nutty taste somewhere between a walnut and a pecan' ('Athletes given swarm reception').

The story that really focused our attention on this pesky, if potentially palatable, Aussie native was the Great Canberra Currawong Catastrophe of October 2003. This event would almost certainly not have hit the international news were it not for the fact that the federal capital was just about to be graced by a visitation by a US President, and efforts had been made to spruce it up for the occasion. Perhaps if he had have been resident in Canberra, as is the custom for Australian Prime Ministers, the President's loyal 'sheriff', John Howard, might have sought 
to dissuade his American mate from coming 'down under' during the bogong moth season. As it was, though, just around the time that George Bush was due to make his eagerly awaited appearance, Parliament House came under major moth attack. As Graeme Dobell recently observed, this moth visitation provides an 'annual example of the law of unintended consequences, in even the most planned environment. Australia spent one billion dollars to build the house with the huge flagpole. But in all that planning, no one factored in the migration of bogongs'. Clearly, the President had to be shielded from this unpleasant and potentially embarrassing infestation of tawny intruders. The parliamentary window ledges, along with sundry other architectural nooks, crannies and orifices, were duly sprayed with liberal quantities of Cislin 10, a pyrethrum-based insecticide, and extra gardeners were employed to come at dawn to sweep up the casualties that had piled up during the night, hauling them away by the wheelbarrow load. Notwithstanding the increased media attention turned upon Canberra at this time, it is unlikely that this in itself would have been considered newsworthy, were it not that birds too began to be found among the dead. In all, fourteen currawongs are said to have fallen victim to this moth eradication campaign, presumably (although this was never proven conclusively) from the ingestion of poisoned insects. In the following weeks, moreover, and for reasons that remain obscure, magpies as well as currawongs shunned Capital Hill, the modest rise within which, in a tremendous feat of architectural prowess, Australia's parliamentary seat of power is sited. While the deaths of thousands of moths might have been a matter of indifference, the idea that the grounds of our flash New Parliament House were littered with big black bird carcasses, right when the eyes of the world were trained upon the federal capital, suddenly made the treatment of bogongs a matter of national concern.

\section{Agrotis infusa}

In an effort to learn more about this undesirable intruder, and in the hope of finding it less loathsome on closer acquaintance, I thought I would begin by having a look at what the entomologists have to say about the bogong.

In Australia, Agrotis infusa, as it is known to Western science, typically begins and ends its life-cycle on the slopes and plains west of the Great Dividing Range in northern New South Wales and southern Queensland. Each spring, swarms of adult moths fly south into the Snowy Mountains of southern New South Wales and northern Victoria in search of the cool dark crevices in alpine blockstreams, cavernous piles of granite boulders, where they while away the hot summer months in a process known as 'aestivation'. There they make themselves collectively cosy during the day by tucking their heads under one another's wings, covering the rock walls like scales or roof tiles. 


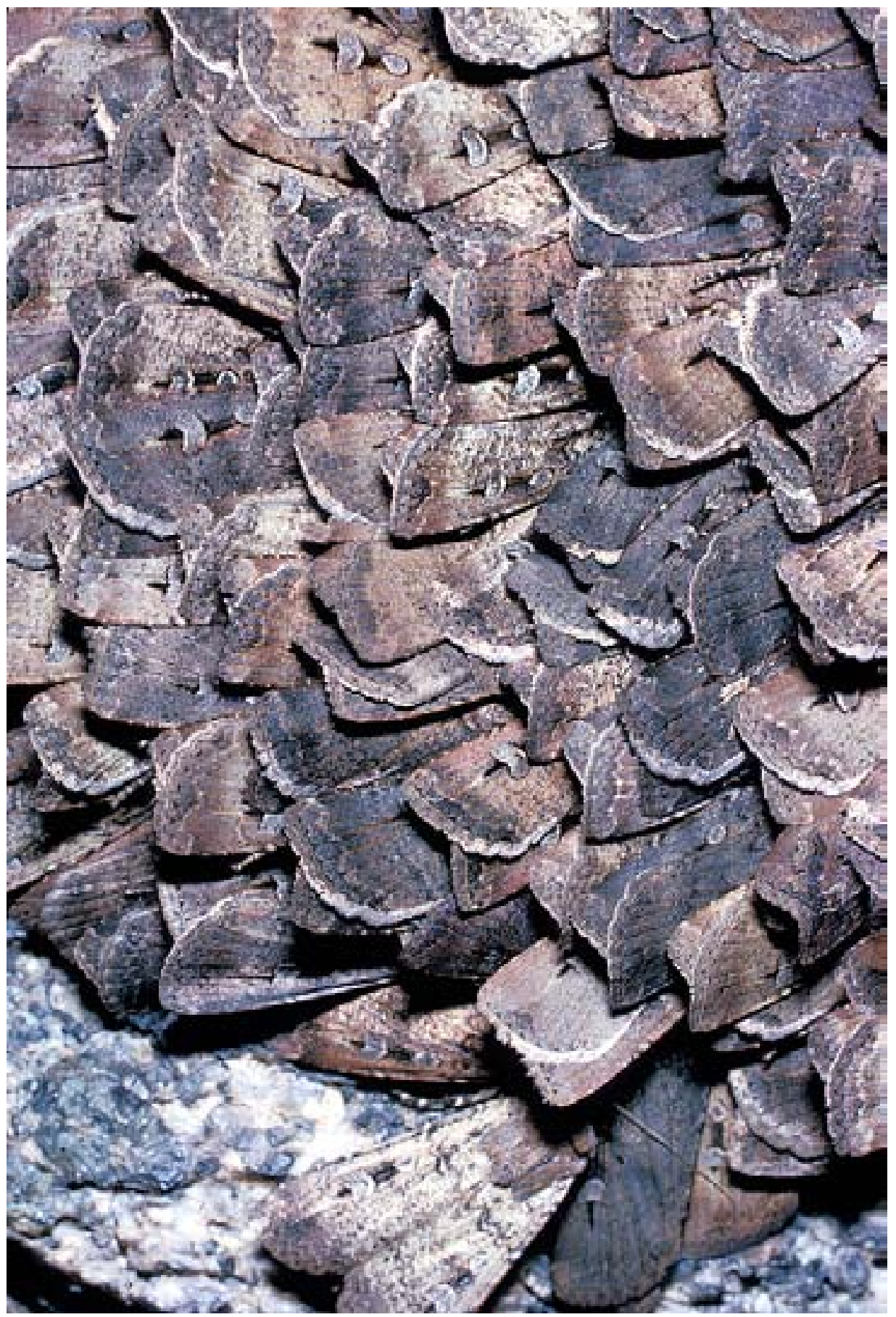

Aestivating bogong moths

Credit: Image (C) CSIRO 
The urge to set off on this annual migration appears to be triggered by the drop in barometric pressure that accompanies the formation of summer storms. The moths travel by night, upwards of 1,000 kilometres in some cases, feeding on nectar along the way, and dropping down to ground to shelter during the day.

This was always a potentially perilous journey, but it became a whole lot more so during the twentieth century. In addition to the perennial risk of being blown off course and towards the eastern seaboard by westerly storm winds, the growth of towns illuminated ever more brightly by electric lights has proven a not infrequently fatal attraction for migrating moths. It is thought that the lights 'fool the moths into behaving as if the sun was coming up. Their natural response is to dive down to the ground to find a dark place before the heat of the day sets in. ... Buildings can become covered with a thick coating of moths, desperately seeking dark cracks and crevasses to hide from the sun' ('Bogong Moths Migrating South'). Those that end up in Sydney, not to mention Melbourne, have gone seriously astray, probably as a result of stormy weather; but Canberra is right in their flight path, and, in addition to the domestic illumination of its sprawling suburbs, the 40,000 lights of the New Parliament House, with its elevated floodlit flagpole beckoning from afar, burn long and strong. Little wonder that the pollies have moths to contend with during their spring sitting (as if the constant incursions of reporters and lobbyists weren't quite bad enough).

Bogongs that manage to survive the risks posed by storms, predators, poisons and the odd book-wielding student during their southern sojourn, return north to their breeding grounds in the relative cool of the autumn. Now that they are all grown up, they duly mate, whereupon the pregnant females cleverly lay their eggs on the stems of a variety of food plants. Previously native species, these are now all too often agricultural crops, such as cauliflower, silverbeet, lucerne, flax and sundry cereals. Needless to say, this practice has ensured that bogongs are if anything even more hated by farmers than by city slickers such as myself. When the larvae emerge in the guise of hungry caterpillars, creamy-coloured to begin with, then green, and finally grey, black or orange-brown in hue, they each make themselves a snug burrow in the soil at the base of their host plant. There they hide by day, craftily emerging under the cover of darkness to feed. This nightly feasting is bad news for seedlings, the stems of which are often gnawed right through, leading bogongs to be classed as a pestiferous 'cutworm' and, for the past fifty to one hundred years, regularly doused in an array of biocidal chemicals.

Adult caterpillars who have been fortunate enough to avoid being devoured by insectivores or poisoned by insecticides eventually hunker down in their burrows to pupate, emerging four weeks later, miraculously metamorphosed into moths. On closer inspection, these turn out to be not entirely unprepossessing 
characters. With a wingspan of about five centimeters, bogongs vary in colour from light brown to almost black, and all sport a distinctive and really rather dashing dark, arrow-like streak, broken by two paler spots, one round and one comma-shaped, on each forewing. 'The hind wings are light brown with a darker border', according to Herbisson-Evans and Crossley, who add, poetically, 'At rest the moth holds its wings like a tent over its body' (Herbisson-Evans and Crossley).

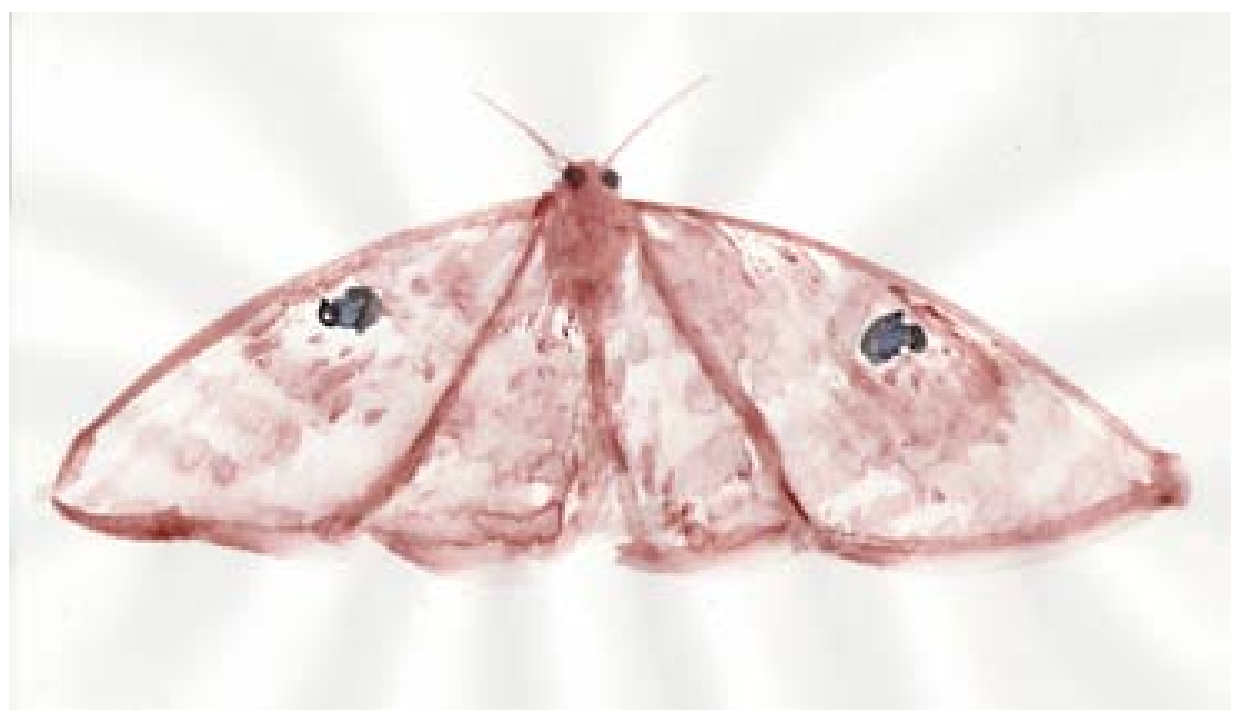

'Bogong Moth' (original artwork courtesy of Deborah Bird Rose)

\section{Corroborees and cakes}

The bogong moth is one of many creatures whose migratory life-cycles have helped over time to form the warp and weft of more-than-human life on this continent, weaving species and places together into complex patterns of collective flourishing. As we have seen, the existence of this tawny insect has become entangled with that of humans in settler Australia in a largely antagonistic manner, both on the land and in town, most notably in the federal capital. In the course of my research into the socio-ecological history of the Canberra area, however, I have discovered that the bogong continues to hold a far more valued place within Indigenous culture: namely, as seriously good eating.

In his 1927 History of and Legends relating to the Federal Capital Territory of the Commonwealth of Australia, long-time resident and well-known journalist and public figure, John Gale, records a conversation with the late Mrs John 
McDonald', whose husband then owned the pastoral property 'Urayarra' on the western banks of the Murrumbidgee River not far from Canberra. Claiming that the name of their property was taken from an Aboriginal expression meaning 'running to the feast', Mrs McDonald related how hundreds of 'blacks and gins' with their 'piccaninnies' from neighbouring districts used to foregather in the nearby mountains every spring and summer to feast on the 'boogong moths' [sic] that 'swarmed' the heights. She linked the name 'Urayarra' to a large flat rock on their property, which she recalled being heated in order to roast the harvest of moths that had been brought back down from the mountains in dilly bags. In good seasons, she claimed, the feast would continue for weeks around this rock, providing an opportunity for much socialising and 'lounging around. ... It was a season of luscious feeling, something so far better than possums and yams, that the ebon skins of the eaters literally shone, and their bodies showed a plumpness quite in contrast with the leanness of normal times' (57-8).

The importance of the bogong within the Indigenous culture of the southern Alpine region has been researched most extensively by the archaeologist Josephine Flood, whose prehistory of the Australian Alps pays homage to this delicious insect in its title, The Moth Hunters. While she found references to the annual moth feast in the writings of a number of non-Indigenous observers, Flood could identify only one eyewitness account of the process of hunting and cooking. This was provided to the entomologist A. W. Scott by one Robert Vyner, who reported ascending the mountain known as 'Numoiadonga' in the Bogong Mountains with an Aboriginal guide, whom he referred to as Old Wellington, in 1865. In an article published in the journal of the NSW Entomological Society in 1869 , Scott wrote that Vyner found that the rock crevices on the peak were:

literally covered with these insects, packed closely side by side, over head and under, presenting a dark surface of a scale-like pattern-each moth was resting firmly by its feet on the rock, and not on the back of others, as in a swarm of bees. So numerous were these moths that six bushels of them could easily have been gathered by the party at this one peak; so abundant were the remains of the former occupants that a stick was thrust into the debris on the floor to a depth of four feet. (Scott, qtd in Flood 61)

In this account, Old Wellington demonstrated how the moths were collected and prepared in the following manner:

a blanket or sheet of bark is spread on the floor: the moths, on being disturbed with a stick fall down, are gathered up before they have time to crawl or fly away, and thrust into a bag. To cook them a hole is made in a sandy spot and a smart fire lit on it until the sand is thoroughly heated, when all portions left of the glowing coal are carefully picked out, for 
fear of scorching the bodies of the insects - as in such a case a violent storm would inevitably arise, according to their superstitious notions. The moths are now poured out of the bag, stirred about in the hot ashes for a short time, and then placed upon a sheet of bark until cold. The next process is to sift them carefully in a net, by which action the heads fall through, and thus the wings and legs having been previously singed off, the bodies are obtained properly prepared. In this state they are generally eaten, but sometimes they are ground into a paste by the use of a smooth stone and hollow piece of bark, and made into cakes. (61-2)

Having begun to conceive an odd fondness for the bogong in the course of my research, I was pleased to read in another account quoted by Flood, that of the anthropologist Richard Helms from 1895, that the moths were commonly stunned by the smoke of smouldering branches before being collected for cooking, so possibly suffered less in the process. Helms, drawing on the testimony of old settlers, also describes with admiration the 'fine nets made of kurrajong fibre' in which the stupefied moths were collected. These, he says, 'had very fine meshes and were manufactured [by the women] with great care, and being attached to a couple of poles they could be readily folded up when they had to be withdrawn from the crevices (Helms, qtd in Flood 66). According to both Helms and the traveller George Bennett, who ascended Mt. Bogong with a group of Indigenous men in 1832, the alpine moth feast generally lasted for up to three months over summer. Bennett reports also that some of the moth cakes were smoked and cured, enabling them to keep fresh longer, presumably so that they could be carried back down into the valleys for later delectation (Flood 67). As for the flavour of the roasted moths, Flood's sources concur that they have a pleasant sweetish nutty taste. Vyner, who was evidently treated to quite a meal of bogongs by Old Wellington, found them so delicious that he 'desired to have "another feed"' (Scott, qtd in Flood 61) - a response shared by my friend Darrell Lewis, who assisted Flood in her identification of moth hunting sites, and acquired quite a taste for the critters in the process.

The average fat content of the edible abdomens of bogongs is over $61 \%$ for males and $51 \%$ for females (Flood 81), and many of Flood's sources comment on the salutary effect of the annual moth feast on the skin and physique of the assembled 'tribes', and even, according to E. J. Eyre, that of their 'wretched halfstarved dogs' (Eyre 1859, qtd. Flood, 70). Even though the moth supply was not consistent, varying in size and availability from year to year, and occasionally failing entirely, Flood makes a convincing case for the importance of the moth feast in the annual subsistence round of Indigenous uplanders. While most of her ethnohistorical sources imply that the actual hunt was a male only affair, it is clear that women and children (and apparently dogs) also got to share in the bounty of the peaks. 
Flood nonetheless stresses that the significance of the moth hunt was far more than nutritional, affording the occasion for very large inter-tribal gatherings, bringing together Ngarigo, Walgalu and Ngunawal in the Canberra region, and possibly involving also the Thaua, Djininganj and Walbanga, during which a range of social, economic and ceremonial business could be conducted. This included major all-in corroborrees down on the plains prior to the ascent, trade transactions, and probably also male initiation rites up on at least some of the peaks, where each group of hunters appear to have had their own pitch (74-76). In this and other ways, the humble bogong emerges as a Hermes of sorts, prompting and facilitating communication along various channels, both among human groups and between humans and other species. While news of the availability of the aestivating moths was conveyed to more distant groups by smoke signals (74), their arrival was made known to the locals by the crows that could be seen circling the granite outcrops in order to enjoy the first fruits of the harvest (66). The living Earth, as biosemiotics has taught us to recognise, is an incredibly complex communications system, with dynamically evolving and self-transforming regional networks. Change is by no means always privative. But it is clear that the British colonisation of Australia ruptured many of the particular, culturally-nurtured networks of interspecies semiosis, such as that in which the bogong played a central role, with fatal consequences for many, human and otherwise. According to the sources studied by Flood, bogong feasts continued at least into the 1850s, 'but by 1878 had irrevocably disappeared' (73).

\section{Postcolonial cuisine}

Growing up in Canberra during the 1960s, I had no idea that the name of my hometown was derived from an Aboriginal term, Ngambri, believed to mean 'meeting place', and I was blissfully ignorant of the dispossession of those for whom this area been for millennia a 'nourishing terrain' (Rose; Jackson-Nakano; Gammage). I would certainly never have guessed that you could have made a meal of those horrid moths. These days, though, Canberra school children on excursion to Namadgi National Park are likely to be treated to a taste of roasted bogong in the context of learning about local Indigenous culture. Within the public space of the federal capital, the world of the Kamberri is recalled in the guise of sundry bogong sculptures, such as those that grace the grounds of the Australian Institute of Aboriginal and Torres Strait Islander Studies on the Acton Peninsula, once a major corroboree site. 


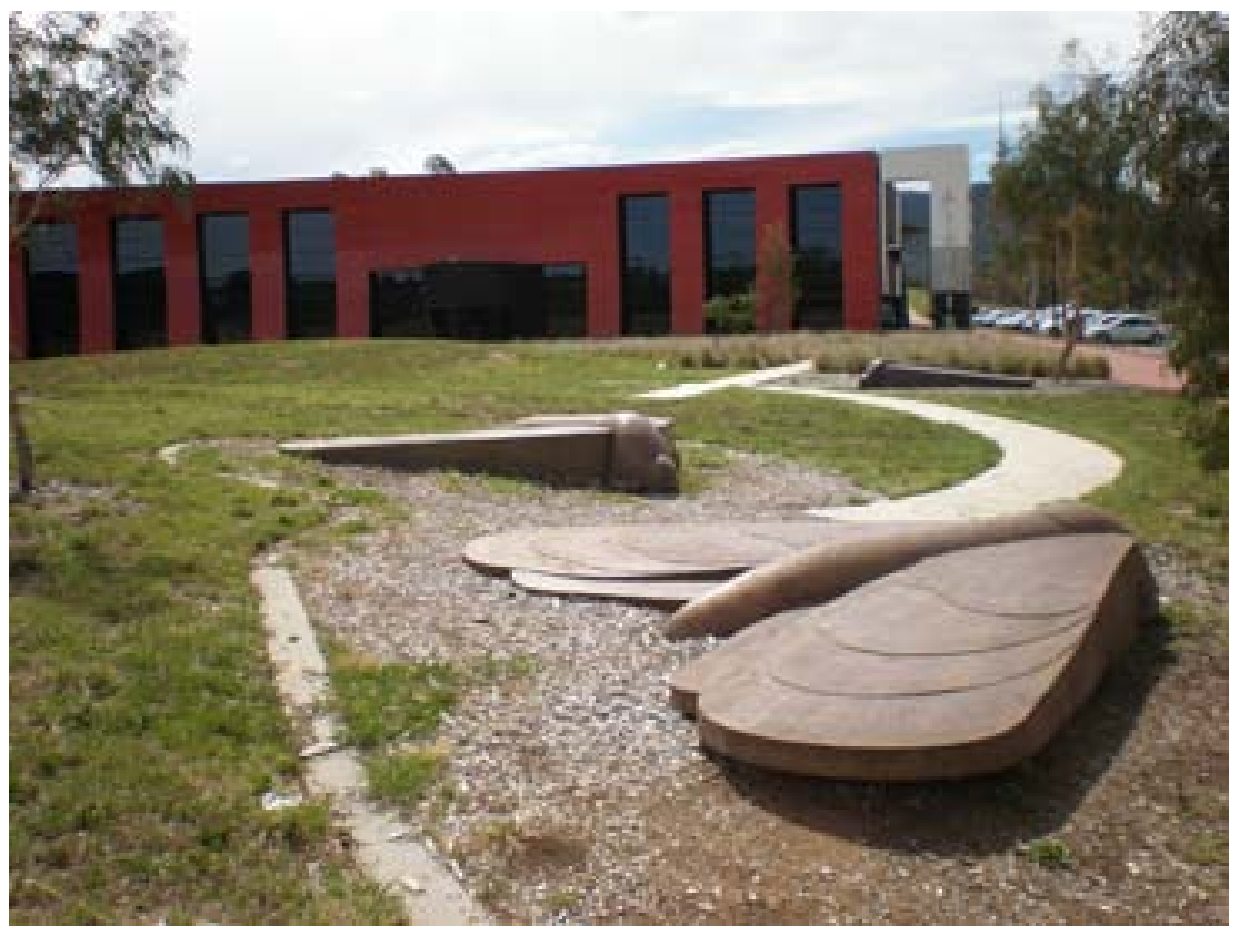

Bogong moth sculpture, AIATSIS, ACT

Further south, near Albury in the hard-pressed Murray-Darling Basin, a Bogong Moth or, as it is now called, Ngan Girra ('gathering place') Festival is held every year on the last Saturday of November, featuring 'indigenous performers, spear and boomerang throwing competitions, bush tucker and indigenous kids' activities' ('Bogong Moths').

The bogong, it seems, has become something of a tourist attraction and even an icon of decolonisation, figuring as a metonym for the ancient lifeways and cultural resurgence of Indigenous Australians. But what of the bogong itself? The recognition that is belatedly being accorded to Indigenous practices of land holdership, practices, that is to say, that care for country while crafting a specifically human life within its bounds, potentially opens a path towards a decolonisation also of settler Australian relations with the more-than-human life of the land. But to travel this path requires that in the figure of the bogong we learn to honour not only the moth hunters, but the moths themselves. And could it be, I wonder, that for this unloved other the best way to human hearts might be through our stomachs?

Clearly, this is not an argument that is likely to go down well with doctrinaire vegetarians. 'Don't eat anything with a face': so goes the Animal Rights maxim (Singer and Dover 186). And the bogong definitely has a face: I can vouch 
for that. Oddly enough, on the night before I embarked on this essay, I was startled to hear a strange banging on my uncurtained kitchen windows in the Dandenong Ranges, east of Melbourne. It turned out to be a mob of about a dozen moths that had evidently gone seriously astray en route to the alpine regions to the north. They calmed down when I turned off the lights in the next room, but remained on the pane long enough for me to get a really good look at them. Up close, their seemingly furry underbellies, layered like a 1920s flapper's dress and gently ruffled by the breeze, looked quite fetching and strangely mammalian. As I continued my appraisal, individual differences in size, marking and even comportment began to emerge. Suddenly, I sensed that the inspection was mutual, as I found myself held in the gaze of several sets of very large eyes.

This was not quite as moving as the face-to-face that I once had on a country path in Germany with a young heifer, destined for the knackers. On that occasion, I fled home in tears, declaring that I was never going to eat meat again. I confess that I did not keep this resolve, although I do insist on free range and not too young, and I prefer my animal tucker to be ecologically raised and humanely slaughtered. Admittedly, this flesh-eating behaviour is in large part motivated by my own animal appetites, which I am reluctant to suppress, and of which I am largely unashamed (although they do cause me some embarrassment at times): after all, my own unruly animality is surely a primary source of the fellow feeling that feeds my compassion for my other-than-human kin. Moreover, I have come to share Val Plumwood's view that the argument about the face is not a terribly sound basis for an ecological ethics of food.

Within the ethical framework of animal rights/animal liberation, the face functions as a signifier of the presence of consciousness or sentience, and it is this which is taken to divide the class of those entities that are not available to be eaten by humans from those that are. The problem with this line of argumentation is that it necessarily leaves most of the non-human world out in the cold, on the far side of ethical considerability. Peter Singer, for example, maintains that in addition to fellow mammals we should include birds, fish, reptiles and other vertebrates among those that we should not eat, namely, on the grounds of their capacity to experience pain, while suggesting that molluscs, such as oysters, can probably be consumed with a clear conscience (unless you're an orthodox Jew, of course: but that's another story). About insects he is 'agnostic' (11), but he has absolutely no qualms about the ethical exclusion of plants: 'Such a life is a complete blank; I would not in the least regret shortening this subjectively barren form of existence' (Singer, qtd in Plumwood 149). As Plumwood observes, 'Singer's methodology organizes the 
diverse and continuous field of mind and ethics into a polarized, simple on-off form - that of consciousness or nothing ... in just the same way as Descartes' (149), thereby reinforcing an implicitly Cartesian reason-nature dualism.

While such arguments might be effective in enlarging the class of beings deemed worthy of ethical consideration, they presuppose a highly problematic, and characteristically modern, separation of those entities that can be used and those which must be respected. In Plumwood's analysis 'the refusal to allow anything morally considerable to be ontologised as edible or useful results in a deep rejection of ecological embodiment for those beings, since all ecologicallyembodied beings are food for some other beings' (156). Translated to the level of landscape, moreover, this use-respect divide gives rise to the cordoning off of certain areas as 'pristine wilderness', while freeing the rest for ruthless exploitation, whether in the guise of mineral extraction, waste dumps or intensive food production. In the Australian context, where national parks are by definition 'native', while the animals and plants raised for food in farms are almost exclusively 'exotic', this has had a further worrisome consequence: the refusal, on the part of the dominant settler culture, 'to partake of the land', as Freya Mathews puts it, 'to 'know' it in a carnal sense' (41). Although it is clear that some native plants and animals were consumed by settler Australians, from the dicey days of food shortages in the fledgling penal colony in Botany Bay through much of the nineteenth century, virtually none became staples of the Anglo-Australian diet. By 1900, with the development of new strains of wheat better suited to Australian conditions, the discovery and exploitation of the Great Artesian Basin, and the deployment of an ever-growing arsenal of fertilizers, biocides and heavy machinery, commercial food production in Australia had really begun to take off - and it was devoted to the provision of precisely those consumables that had been brought from other continents in the well-stocked hold of the First Fleet (Symons). As Mathews observes, 'our colonial forbears brought with them their entire biological-and hence dietary-repertoire of plants and animals. They came here, figuratively speaking, in a European Noah's ark, and we have for all practical purposes remained within that supply ship' (41). Impeded, not only by culinary preference but also by racial prejudice, from assimilating the food culture of those people whose land they claimed for their own euro-western purposes, settler Australians have been largely unable to embrace indigenous geo-cultural landscapes as a nourishing terrain, reducing them instead to the one-dimensionality of either lucrative 'resource' or attractive 'scenery'.

Over the past decade or so, though, this colonial and colonizing use-respect boundary has begun to be breached in a number of promising ways. As national parks increasingly come under joint management with Indigenous land-holders, visitors are invited to experience such places not as 'wilderness', 
but as 'country', a multi-dimensional human homeland, where the recognition of kinship with, and the respectful consumption of non-human others have always been conjoined. Meanwhile, with the expansion of landcare practices within agriculture, many Australian farmers are endeavouring to find ways of reconciling commercial and ecological considerations. Indeed, for some landscape types, notably grasslands with scattered trees, or grassy woodlands, the integration of conservation and production across the use-respect boundary is crucial for the survival of many species (Manning, Fischer and Lindenmayer). Following the success of the television series Bush Tucker Man, which first aired on the $\mathrm{ABC}$ in the late 1980s, moreover, some enterprising farmers have also begun to cultivate native food species ('Bush Tucker on a Commercial Scale'). These days, you can even buy kanga at some Coles supermarkets.

When it comes to the ethics of eating, though, context is crucial. Consuming roo, wattle seeds and warrigal greens, not to mention migratory moths, is insufficient in itself to the decolonization of the Australian diet. It could simply imply the relocation of the formerly respected, reviled or simply ignored into the use category. And there are also tricky social questions pertaining to 'race' and class with regard to who actually benefits from the consumption of what.

This is brought home in a 2003 novel by the well-known Canberra author, Marion Halligan, about which I have previously written elsewhere ('Ecopoetics of the Limestone Plains'). Its title, The Point, refers to the imaginary restaurant on an equally imaginary promontory of Canberra's Lake Burley Griffin that provides the central locus, and tropological focus, of Halligan's tale. Reputed to be the best restaurant in town, The Point caters largely to jet-setting businessmen, politicians, diplomats, journalists and other well-heeled professionals, a microcosm of the privileged demographic of the capital city. These are, as the narrator observes, 'those who possess, and are perhaps themselves possessed. Outside are the dispossessed'. Based on one of Marion Mahony Griffin's beautiful drawings for her husband's prize-winning entry in the Federal Capital Competition of 1911, The Point is an octagonal building, and seven of its eight walls are made entirely of glass. At night, when the restaurant is illuminated like a lantern, 'the dispossessed see themselves, and the others, the insiders'. For the insiders, though, the glass walls function like a mirror, such that they 'see only themselves' (1-2).

The cuisine that is concocted here by the innovative chef de maison, Flora Mount, is also emphatically cosmopolitan, as well as decidedly postmodern, featuring such kitsch '60s dishes as oysters Rockefeller and chicken Kiev, revisited with a subversive twist, and erstwhile working-class staples, like tripe, reinvented as an exotic delicacy. Witchetty grubs, something of a cliché of bush tucker, are also on the menu. This surprising inclusion does not necessarily signal respect for Indigenous traditions or bioregional specificities, however: on the 
contrary, it merely demonstrates that for Flora and her cosmopolitan clientele, anything from anywhere is now available to be transformed into a postmodern work of culinary art. Towards the end of the novel, however, Flora imports a new political agenda into her cooking feats in the guise of the 'virtuous globalisation' (267) embodied by the Slow Food Movement. It is while she is pondering her contribution to a forthcoming Slow Food dinner that the tragic denouement of the novel is brought about by the unexpected intrusion into the elegantly cosmopolitan and exclusively human world of The Point of an abject other-than-human native: a hapless bogong who flies into her kitchen one night through an open window. Recalling the feasts of the indigenous Kamberri, Flora decides that moth cakes would be the perfect thing to add local colour to her eclectic menu, and sets about catching the other moths that had followed the first. Her second-hand knowledge, though, is inadequate, and, ironically, her time is short. In her haste, she makes a fatal mistake. The rock she takes inside on which to roast her moths is a river stone, a remnant of pre-lake days, which explodes when she heats it, causing a conflagration that kills the cook and destroys her restaurant, as well as injuring the destitute teenage girl sleeping outside.

The catastrophic outcome of Flora Mount's moth cake project, undertaken in the absence of Aboriginal instruction, and for the benefit of a largely non-indigenous urban elite, might be taken as emblematic of a false reconciliation: although well-intentioned, this looks more like appropriation than decolonisation.

\section{Food for other others}

It does not have to be like this, though. The creation of a culinary culture of partaking in the indigenous bounty of the places where we reside, with due regard to the flourishing of their more-than-human life, and in true fellowship with those whose forbears upheld it so skillfully in the past, would constitute a crucial step forward along the path of reconciliation, both between Indigenous and settler Australians, and between the latter and the land. Given the far larger number of humans that now populates the southern highlands, there would of course only be a modest serving of moths, if all were to have a fair share. Even still, I am sure that if we valued them as food, we would be far more concerned about the current condition of bogong moths.

For one thing, if we lived or worked in their flight path, we would be making sure that we turned off our lights, as Canberra's parliamentarians have reportedly learnt to do on leaving their offices (thereby also reducing both the tax-payer subsidized electricity bill and the greenhouse gas emissions of 'the peoples' house' (McCormick, 10)). Secondly, we would surely be raising the alarm about the declining numbers of migrating moths. While the causes of this decline remain 
uncertain, the clear-felling of native vegetation in their breeding grounds and liberal use of biocides on the cropland that has replaced it are likely to be factors (Keaney). The industrial production of preferred settler Australian foodstuffs, and possibly other lucrative plants, in the bogong breeding grounds also appears to be threatening more than the moths themselves. A paper published in 2001 (Green et al.) found that the raised levels of arsenic found in the outwash areas of those caves where bogongs had been aestivating over summer indicated that the moths were importing poison into the alps. Moreover, arsenic was also found in the faeces of mammals that prey on them, including bats and mountain pygmy possums, an already endangered species. The source of this arsenic could well be from accumulations in the soil, a legacy of its former use in pesticides, as well as in cattle and sheep dips, in lowland agriculture: the story of the bogong discloses connections across time as well as space. However, the authors note that an arsenic-based insecticide is still licensed for agricultural use in New South Wales, in the form of monosodium methylarsonate (MSMA). According to McCormick (11), MSMA is mainly deployed as a post-emergent herbicide in cotton production: another good reason, if appears, to scale back this waterhungry industry and to prefer organic purchases (although, at present, that means not buying Australian ('Organic cotton')). Finally, if we want to have a chance to join the more-than-human bogong feast at some future date, once we have re-vegetated and detoxified their regional breeding grounds, we will need to do whatever we can to ensure adequate climate change mitigation measures are undertaken globally: for if those alpine block streams get too warm, the bogongs will have nowhere left to find shelter from the heat of summer days.

In view of the multiple threats to the bogong, including the arsenic that these hard-pressed critters are currently carrying in their fatty abdomens, it seems that we will not be able to learn to love them as a regular part of our own diet after all, at least for the time being. Regrettably, the bogong also lacks the potentially compensatory charisma that has enabled other species, most famously the polar bear, to become a pin-up creature for conservation and climate change mitigation. Perhaps, then, the best chance for the bogong is to be honoured as food, not so much for ourselves, but for other others, both human and otherwise, as they were for long ages in the past; as they remain for some non-humans today; and as they might yet become for our own descendents, in company with a diversity of other predators, in a currently barely imaginable, deeply sustainable future.

\section{Parliamentary postscript}

Reversing the trend of declining numbers, spring 2009 was once again a bumper year for bogongs in Canberra. In light of Halligan's cautionary tale, and in view of the moths' reportedly high levels of arsenic, I had mixed feelings to learn 
that one enterprising restaurateur in Canberra was prowling parliamentary offices, netting them for his eatery (Yaxley). Pondering the return of the bogong in huge, unruly numbers to Parliament House, though, I am suddenly taken by the thought that they should not simply be viewed as victims, seduced by the city lights, but might instead be hailed as unintentional lobbyists of sorts: insinuating themselves amongst the pages of Hansard, disrupting the humanall-too-human business of the day, and obliging even the climate change sceptics to remember to turn off their lights at night, might they not be acting, however unwittingly, as emissaries from an other-than-human world that is no longer going to put up with being relegated to the background, whether as scenery or resource? ABC political reporter, Louise Yaxley, who has lived through fifteen bogong visitations to Parliament House, commenting on the 2009 migration, exemplifies a new sensibility in Canberra:

In this building in bogong time there's the occasional slapping sound as a full speed moth hits you in the back or the face. There are even contemplative moments of gazing into a tiny face when it's arrived on a desk apparently attempting to pioneer some inter-species communication. ... So for a few weeks in Parliament House in Spring there's a living, flapping link with the Indigenous culture in this region - when the insects' arrival was a nutritious post-winter pick-meup. ... It's a strange privilege to be a stopover on their annual journey to the snowy mountains, but I love their visit. I welcome their company and I mourn for all their fallen.

Unloved though they have been within settler Australian culture hitherto, I like to imagine that these tawny intruders are now acting as an advance guard of sorts, nudging us towards the long overdue inauguration of a more inclusive parliament: one, that is, which would seek to rule in the interest, not just of human citizens, but of all beings (Serres).

Kate Rigby is Associate Professor of Comparative Literature and Cultural Studies at Monash University, Australia. Among her many publications on literature, religion and ecology are her latest book, Topographies of the Sacred: The Poetics of Place in European Romanticism (2004), and a co-edited volume, Ecology, Gender and the Sacred (1999). 


\section{Works Cited}

'Athletes given swarm reception.' BBC Sport On-line, 23 September 2000. <http://news.bbc.co.uk/sport2/hi/olympics2000/athletics-track/938449. stm> Accessed 4 May 2009.

'Bogongs Migrating South.' Scribbly Gum, ABC Science Online, 14 November 2002. <http://www.abc.net.au/science/scribblygum/november2002> Accessed 15 Jul. 2009.

'Bogong Moths.' Basin Kids. Murray Darling Basin Commission. <http://kids. mdbc.gov.au/encyclopedia/wildlife/invertebrates/bogong_moth $>$ Accessed 28 Sep. 2009.

'Bush Tucker on a Commercial Scale.' Landcare Online. Landcare Australia. $<$ http://www.landcareonline.com/case_study.asp?cID=163> Accessed 29 Sep. 2009.

Chief Health Officer, Victoria, Australia. 'January 2009 Heatwave in Victoria.' <http://www.health.vic.gov.au/chiefhealthofficer/publications/heatwave. htm $>$ Accessed 4 May 2009.

Dobell, Graeme. 'Aussie Bogongs, Pommie Mice.' The Interpreter, 12 April 2010. Lowy Institute for International Policy. <http://www.lowyinterpreter.org/ post/2010/04/12/Aussie-bogongs-Pommy-mice.aspx $>$ Accessed 4 Oct. 2010.

Manning, Adrian D., et al. 'Scattered trees are keystone structures-Implications for Conservation.' Biological Conservation 132 (2009): 311-321.

Flood, Josephine. The Moth Hunters: Aboriginal Prehistory of the Australian Alps. Canberra: Australian Institute of Aboriginal Studies, 1980.

Gale, John. Canberra: History of and Legends Relating to the Federal Capital Territory of the Commonwealth of Australia. Queanbeyan: A. M. Pallick \& Sons, 1927.

Gammage, Bill. Australia under Aboriginal Land Management. Fifteenth Barry Andrews Memorial Lecture. Canberra: University College, ADFA, 2002.

Green, K. et al. 'Long distance transport of arsenic by migrating Bogong moths from agricultural lowlands to mountain ecosystems.' The Victorian Naturalist 118 (2001): 112-116.

Halligan, Marion. The Point. Crows Nest: Allen and Unwin, 2003.

Herbison-Evans, Don and Stella Crossley. 'Agrotis infusa.' <http://www-staff. it.uts.edu.au/ don/larvae/noct/infusa.html> Accessed 4 May 2009. 
Jackson-Nakano, Ann. The Kanberri. A History from the Records of Aboriginal Families in the Canberra-Queanbeyan District and Surrounds 1820-27, and Historical Overview 1928-2001. Weereewaa History Series, vol. 1. Canberra: Aboriginal History, 2001.

Keaney, Ben. 'Bogong Moth.' ACT GreenGuide, 2009. <http://act.greenguide. net.au/Bogong_Moth> Accessed 15 Jul. 2009.

Linden, Julian. 'Heatwave causes havoc at Australian Open.' Reuters, 28 January 2009. <http://www.reuters.com/article/sportsNews/ idUSTRE50R0W720090128> Accessed 4 May 2009.

McCormick, Bill. 'Bogong Moths and Parliament House.' Research Brief, Parliament of Australia, Department of Parliamentary Services (18 December 2006, No. 6). Canberra: Parliamentary Library, 2006.

Mathews, Freya. 'Carnal Legacies.' Terra Incognita. Ed. Laurie Cosgrove et al. Carlton: Melbourne UP, 1994. 37-46.

'Organic cotton: Reduce your impact one t-shirt at a time.' Greenhome: ACF online. <http://www.acfonline.org.au/articles/news.asp?news_id=1921> Accessed 1 Oct. 2009.

Plumwood, Val. Environmental Culture: The Ecological Crisis of Reason. London: Routledge, 2002.

Rigby, Kate. 'Ecopoetics of the Limestone Plains.' The Littoral Zone. Australian Contexts and their Writers. Ed. C.A. Cranston and Robert Zeller. Amstersdam: Rodopi, 2007. 153-75.

Rose, Deborah Bird. Nourishing Terrains:Australian Aboriginal Views of Landscape and Wilderness. Canberra: Australian Heritage Commission, 1996.

Serres, Michel. The Natural Contract. Trans. Elizabeth MacArthur and William Paulson. Ann Arbor: U of Michigan P, 1995.

Singer, Peter. 'Animal Liberation.' Animal Rights: The Changing Debate. Ed. Robert Garner. Basingstoke: Macmillan, 1996. 7-18.

-, and Barbara Dover. Save the Animals! 101 Easy Things You Can Do. North Ryde: HarperCollins, 1991.

Symons, Michael. One Continuous Picnic: A Gastronomic History of Australia. Carlton: Melbourne UP, 2007.

Yaxley, Louise. 'Bogong tour 09 takes over Parliament House.' ABC News, 28 October 2009. <http://www.abc.net.au/news/stories/2009/10/28/2726474. htm $>$ Accessed 20 Nov. 2009. 